\title{
INTERNATIONAL CONFEDERATION OF FREE TRADE UNIONS (ICFTU)
}

Origin. The founding congress of the ICFTU was held in London in Dec. 1949 following the withdrawal of some Western trade unions from the World Federation of Trade Unions (WFTU), which had come under Communist control. The constitution, as amended, provides for co-operation with the UN and the ILO, and for regional organizations to promote free trade unionism, especially in developing countries. By March 2004 the ICFTU represented 150m. workers across 233 national trade union centres in 152 countries and territories.

Aims. The ICFTU aims to promote the interests of working people and to secure recognition of workers' organizations as free bargaining agents; to reduce the gap between rich and poor; and to defend fundamental human and trade union rights. In 1996 it campaigned for the adoption by the WTO of a social clause, with legally binding minimum labour standards.

Organization. The Congress meets every four years. The 17th Annual World Congress was held in Durban in April 2000. The next Congress will be held in Dec. 2004 in Japan. It elects the General Secretary and an Executive Board of 53 members nominated on an area basis for a four-year period. Five seats are reserved for women, nominated by the Women's Committee, and one reserved for a representative of young workers. The Board meets at least once a year. Various committees cover economic and social policy, violation of trade union and other human rights, trade union co-operation projects and also the administration of the International Solidarity Fund. There are joint ICFTU-Global Union Federations for co-ordinating activities.

The ICFTU has branch offices in Geneva and New York, and regional organizations in Latin America (Caracas), Asia (Singapore) and Africa (Nairobi).

Headquarters: Bd. du Roi Albert II, N 5, bte 1, Brussels 1210, Belgium.

Website: http://www.icftu.org

General Secretary (acting): Guy Ryder (UK).

President: Fackson Shamenda (Zambia).

Publications. Trade Union World (monthly); Annual Survey of Violations of Trade Union Rights (annual); ICFTU On-Line (daily electronic news bulletin). Other publications available; contact the press department.

\section{WORLD FEDERATION OF TRADE UNIONS (WFTU)}

Origin and History. The WFTU was founded on a worldwide basis in 1945 at the international trade union conferences held in London and Paris, with the participation of all the trade union centres in the countries of the anti-Hitler coalition. The aim was to reunite the world trade union movement at the end of the Second World War. The acute political differences among affiliates, especially the east-west confrontation in Europe on ideological lines, led to a split. A number of affiliated organizations withdrew in 1949 and established the ICFTU. The WFTU now draws its membership from the industrially developing countries like India, Vietnam and other Asian countries, Brazil, Peru, Cuba and other Latin American countries, Syria, Lebanon, Kuwait and other Arab countries, and it has affiliates and associates in more than 20 European countries. It has close relations with the International Confederation of Arab Trade Unions, the Organization of African Trade Union Unity as well as the All-China Federation of Trade Unions, all of which participated at its Congress in New Delhi, India in 2000. Its Trade Unions Internationals (TUIs) have affiliates in Russia, the Czech Republic, Poland and other East European countries, Portugal, France, Spain, Japan and other OECD countries. 